\title{
Etiological profile of benign esophageal stricture and its management with through-the-scope endoscopic balloon dilation in the western region of Nepal
}

Umid Kumar Shrestha*

Manipal College of Medical Sciences, Paschimanchal Community Hospital, Pokhara, Nepal

DOI Name

http://dx.doi.org/10.3126/jaim.v5i2.17350

\section{Keywords}

Benign esophageal stricture; etiology; peptic stricture; through-the-scope; endoscopic balloon dilation

\section{Citation}

Umid Kumar Shresthha, Etiological profile of benign esophageal stricture and its management with through-the-scope endoscopic balloon dilation in the western region of Nepal. Journal of Advances in Internal Medicine 2016:05(02):29-33.

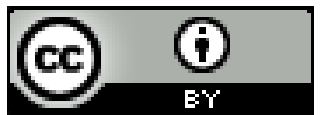

This work is licensed under a Creative Commons Attribution 3.0 Unported License.

\begin{abstract}
Background: Benign esophageal stricture is a common cause of dysphagia with a considerable morbidity and endoscopic balloon dilatation (EBD) is a minimally invasive modality for its treatment. The aim of present study was to determine the etiology of benign esophageal stricture and to evaluate the role of EBD in its management in the western region of Nepal.
\end{abstract}

Methods: This is a prospective descriptive study from December 2012 to September 2016, in which a total of 44 patients with esophageal stricture having benign lesion, confirmed in histopathological examination, were included. Wire-guided through-the-scope EBD of esophageal stricture was performed with Controlled Radial Expansion Balloon to relieve the stricture and the procedure was repeated every two weeks until the symptoms of dysphagia was relieved. The patients were followed up on three months and six months for the assessment of recurrence of dysphagia.

Results: Among 44 patients of benign esophageal stricture [mean age 51.5 years ( \pm 15.6 ; range 18 to 75 years), male $54.5 \%$, female $45.5 \%$ ], the frequency of different etiology was $54.5 \%$ peptic injury, $18.2 \%$ post-radiotherapy, $15.9 \%$ idiopathic, $6.8 \%$ corrosive ingestion and $4.5 \%$ eosinophilic esophagitis. A total of 75 sessions of dilations were performed for 44 patients who had various degrees of dysphagia prior to each session. Among them, increased number of sessions of EBD was needed for stricture caused by corrosive ingestion, postradiotherapy and eosinophilic esophagitis $(p<0.001)$. The technical success rate for EBD was $100 \%$ and there was no any perforation or other complication during the procedure except for minor bleeding at the site of stricture dilation. After a session of one or more dilations, all patients could maintain a solid diet at 6 months of follow up.

Conclusions: Peptic stricture was the commonest cause of benign esophageal stricture followed by post-radiotherapy, idiopathic, corrosive ingestion and eosinophilic esophagitis in the western region of Nepal. The stricture caused by radiotherapy, corrosive ingestion and eosinophilic esophagitis required more sessions of EBD. When performed carefully by an experienced endoscopist, through-the-scope EBD is safe and effective in treating benign esophageal strictures.

\section{INTRODUCTION}

Dysphagia is a common presenting feature of the patient with esophageal stricture, which can be benign or malignant. Malignant esophageal stricture is caused mainly by primary esophageal cancer, but can also be caused by the external compression with extra-esophageal malignancy. ${ }^{1}$ On the other hand, benign esophageal stricture is caused by peptic

\footnotetext{
* Corresponding author

Umid Kumar Shrestha, MD, PhD

Professor, Department of Medicine

Manipal College of Medical Sciences, Pokhara, Nepal

Email: umidshrestha@gmail.com
} 


\section{| Original Article}

injury, post-radiation, corrosive ingestion, congenital, infective, eosinophilic esophagitis, autoimmune, iatrogenic, anastomotic, idiopathic, etc. Upper gastrointestinal endoscopy is required to visualize the stricture and to get the sample of biopsy to confirm whether the stricture is benign or malignant. ${ }^{1}$ Balloon dilation is an established method in the treatment of esophageal stricture and overall success rates are reported to be $67-98 \%$ in prior studies. ${ }^{2-6}$ Prior to dilation, a tissue diagnosis is desirable, not only to differentiate benign from malignant lesion, but also to help in the overall management and to estimate the risk of perforation. ${ }^{7}$ The principal complications of esophageal dilation are perforation, bleeding and pulmonary aspiration. ${ }^{8}$ However, using a balloon during dilation, the risk of esophageal rupture is virtually eliminated. There is a reduced shearing force for the balloon compared with bougie in vivo and this increases the margin of safety. ${ }^{9}$

Unlike bougie dilator, balloon dilator exerts only radial force along the length of the stricture. This circumferential pressure, also called as hoop stress, is a product of the diameter and pressure within the balloon. ${ }^{10}$ An hourglass waist in the balloon is created by the opposing static force of the stricture; the dilating force of a balloon dilator is inversely proportional to the diameter of the waist. ${ }^{10} \mathrm{~A}$ larger balloon that exerts a higher radial force requires less pressure for dilation but may be associated with a higher risk for perforation. ${ }^{11}$ The dilating force is also dependent on the surface area of the stricture, with more effective dilation of longer strictures. ${ }^{12}$

The main objective of treatment of benign esophageal strictures is to relieve the dysphagia by means of dilation; an equally important goal of the treatment of benign esophageal stricture is to prevent the recurrence of the stricture. ${ }^{13}$ However, there has been no study till date about benign esophageal stricture in Nepal. Hence, the aim of our study is to determine the etiology of benign esophageal stricture and its management by endoscopic balloon dilation (EBD) in the western region of Nepal.

\section{METHODS:}

A total of 63 patients, presenting with difficulty in swallowing, underwent upper gastrointestinal endoscopy at Kaski Sewa Hospital, Pokhara, Nepal from December 2012 to May 2015 and at Paschimanchal Community Hospital, Pokhara, Nepal from June 2015 to September 2016. All the patients with esophageal stricture had their biopsy taken from the site of the stricture. Nineteen patients with malignant lesion, external compression and achalasia were excluded from the study. Ultimately, a total of 44 patients were included in this prospective descriptive study. The informed consent was taken from the patient and the approval was taken from the ethics committee of the participating hospital. Apart from endoscopy, barium swallow study and CT scan of chest, along with other relevant investigations, were done prior to the dilation. The clinical profile, regarding onset and duration of dysphagia, regurgitation, heart burn, pain epigastrium and dyspnea, was recorded. History of corrosive substance intake, ingestion of non-steroidal anti-inflammatory drugs and presence of comorbid conditions was documented. The etiology of the benign esophageal stricture was determined by the combination of clinical, endoscopic, radiological and histopathological evidence, and different etiologies such as peptic injury, eosinophilic esophagitis, infective esophagitis, corrosive injury, congenital, iatrogenic, autoimmune and idiopathic, were looked for. Necessary laboratory investigations (such as complete blood count, blood sugar, human immunodeficiency virus, hepatitis $B$ and $C$ status, autoimmune antibody in relevant patients and urine analysis) were performed.

During endoscopy, the location of stricture was categorized into upper third, middle third, lower third and multiple segments. Prior to dilation, patients were kept nil per orally for at least 8 hours or prolonged period to assure a clear view of the esophageal lumen and to avoid aspiration. Patients taking antiplatelet agents and anticoagulants were instructed to avoid medication seven days prior to the procedure. The procedure was done with $10 \%$ xylocaine spray to the throat; during the procedure, the guide wire was placed through the stricture under endoscopic guidance and the balloon was maintained in the stricture and inflated under direct visualization for approximately 30 to 60 seconds or until there is a sudden drop in manometric pressure. The step of balloon inflation was repeated for three times in a single session with a progression of dilation per session up to $3 \mathrm{~mm}$ so as to attain a goal esophageal diameter of $15 \mathrm{~mm}$. This wire-guided throughthe-scope endoscopic dilation of benign esophageal stricture was performed with Controlled Radial Expansion Balloon to relieve the stricture. The patients were allowed liquids orally 6 hours after the procedure and were encouraged to resume intake of semisolid one day after the procedure except for those which developed complications during procedure. After the procedure, all patients were kept under close observation for detection of signs and symptoms of esophageal perforation such as chest pain, back pain, shoulder pain, epigastric tenderness and tachycardia. Plain X-ray chest was done after the procedure for the detection of any possible esophageal perforation as per the recommendation. ${ }^{14}$ 
The patients were initially followed up every 2 weeks till 2 months, and in case of recurrence of dysphagia, the repeat sessions of balloon dilation were performed every two weeks till the symptoms were relieved. Thereafter, the patients were followed up on 3 months and then on 6 months to assess for the recurrence of dysphagia. In peptic esophageal stricture, patients were treated with proton pump inhibitors following esophageal dilation.

\section{RESULTS:}

Among a total 44 patients of benign esophageal stricture, mean age was 51.5 years (standard deviation 15.6 years; range from 18 years to 75 years) with male population of $54.5 \%$ and female $45.5 \%$. The frequency of different etiology of benign esophageal stricture was $54.5 \%$ peptic injury (male 54.2\%, female $45.8 \%$ ), $18.2 \%$ post-radiotherapy (male $75 \%$, female $25 \%$ ), $15.9 \%$ idiopathic (male $71.4 \%$, female $28.6 \%$ ), $6.8 \%$ corrosive (male $0 \%$, female $100 \%$ ) and $4.5 \%$ autoimmune (male $0 \%$, female 100\%). The incidence of different etiology of benign esophageal stricture among different genders was not statistically significant. The etiology of benign esophageal stricture according to the gender and age group is shown in table 1 and table 2.

The location of stricture was categorized into lower third, middle third, upper third and multiple segments of esophagus. The peptic stricture was found in the lower third of esophagus; strictures due to corrosive ingestion and eosinophilic esophagitis were found in the multiple segments and the middle third of esophagus, respectively; similarly, strictures due to radiotherapy and idiopathic were found more in middle third of esophagus $(p<0.001)$. The etiology of benign esophageal stricture according to the location of the stricture is shown in table 3.

A total of 75 sessions of dilations were performed for 44 patients who had various degrees of dysphagia prior to each session. Among them, increased number of sessions of EBD was needed for benign esophageal stricture caused by corrosive injury, radiotherapy and eosinophilic esophagitis, which was statistically significant $(p<0.001)$. The number of sessions of EBD required for different etiology of benign esophageal stricture is shown in table 4.

The technical success rate for the EBD for benign esophageal stricture was $100 \%$ and there was no any perforation or other complication during the procedure except for minor bleeding at the site of stricture dilation. All patients showed the ability to maintain a solid diet for 6 months after one or more sessions of dilations.
Table 1: Etiology of benign esophageal stricture according to the gender

\begin{tabular}{|c|c|c|c|}
\hline $\begin{array}{l}\text { Etiology of benign } \\
\text { esophageal stricture }\end{array}$ & $\begin{array}{c}\text { Male } \\
n=24 \\
(54.5 \%)\end{array}$ & $\begin{array}{c}\text { Female } \\
n=20 \\
(45.5 \%)\end{array}$ & $\begin{array}{l}\text { Total } \\
\mathrm{N}=44\end{array}$ \\
\hline Peptic injury & $13(54.2 \%)$ & $11(45.8 \%)$ & $24(54.5 \%)$ \\
\hline Radiotherapy & $6(75 \%)$ & $2(25 \%)$ & $8(18.2 \%)$ \\
\hline Idiopathic & $5(71.4 \%)$ & $2(28.6 \%)$ & 7 (15.9\%) \\
\hline Corrosive injury & $0(0 \%)$ & $3(100 \%)$ & $3(6.8 \%)$ \\
\hline Eosinophilic esophagitis & $0(0 \%)$ & $2(100 \%)$ & $2(4.5 \%)$ \\
\hline
\end{tabular}

$P>0.05$

Table 2: Etiology of esophageal stricture according to the age group

\begin{tabular}{|c|c|c|c|c|c|c|c|}
\hline \multirow{2}{*}{$\begin{array}{l}\text { Etiology } \\
\text { of benign } \\
\text { esophageal } \\
\text { stricture }\end{array}$} & \multirow[b]{2}{*}{$\begin{array}{l}10-20 \\
n=1\end{array}$} & \multirow[b]{2}{*}{$\begin{array}{l}21-30 \\
n=5\end{array}$} & \multirow[b]{2}{*}{$\begin{array}{l}31-40 \\
n=6\end{array}$} & \multicolumn{4}{|c|}{ Age group (years) } \\
\hline & & & & $\begin{array}{l}41-50 \\
n=8\end{array}$ & $\begin{array}{r}51-60 \\
n=8\end{array}$ & $\begin{array}{c}1-70 \\
n=13\end{array}$ & $\begin{array}{l}>70 \\
n=3\end{array}$ \\
\hline $\begin{array}{l}\text { Peptic injury } \\
(n=24)\end{array}$ & $1(4.2 \%)$ & $1(4.2 \%)$ & $\begin{array}{c}3 \\
(12.5 \%)\end{array}$ & $\begin{array}{c}5 \\
(20.8 \%)\end{array}$ & $6(25 \%)$ & $6(25 \%)$ & $2(8.3 \%)$ \\
\hline $\begin{array}{l}\text { Radiotherapy } \\
(n=8)\end{array}$ & $0(0 \%)$ & $0(0 \%)$ & $0(0 \%)$ & $0(0 \%)$ & $2(25 \%)$ & $\begin{array}{c}5 \\
(62.5 \%)\end{array}$ & $\begin{array}{c}1 \\
(12.5 \%)\end{array}$ \\
\hline $\begin{array}{l}\text { Idiopathic } \\
(n=7)\end{array}$ & $0(0 \%)$ & $\begin{array}{c}1 \\
(14.3 \%)\end{array}$ & $\begin{array}{c}2 \\
(28.6 \%)\end{array}$ & $\begin{array}{c}2 \\
(28.6 \%)\end{array}$ & $0(0 \%)$ & $\begin{array}{c}2 \\
(28.6 \%)\end{array}$ & $0(0 \%)$ \\
\hline $\begin{array}{l}\text { Corrosive } \\
\text { injury }(n=3)\end{array}$ & $0(0 \%)$ & $\begin{array}{c}2 \\
(66.7 \%)\end{array}$ & $0(0 \%)$ & $\begin{array}{c}1 \\
(33.3 \%)\end{array}$ & $0(0 \%)$ & $0(0 \%)$ & $0(0 \%)$ \\
\hline $\begin{array}{l}\text { Eosinophilic } \\
\text { esophagitis } \\
(n=2)\end{array}$ & $0(0 \%)$ & $1(50 \%)$ & $1(50 \%)$ & $0(0 \%)$ & $0(0 \%)$ & $0(0 \%)$ & $0(0 \%)$ \\
\hline
\end{tabular}

$P>0.05$

Table 3: Etiology of esophageal stricture according to the location of the stricture

\begin{tabular}{|c|c|c|c|c|}
\hline \multirow[b]{2}{*}{$\begin{array}{l}\text { Etiology of benign } \\
\text { esophageal stricture }\end{array}$} & \multicolumn{4}{|c|}{ Location of stricture } \\
\hline & $\begin{array}{c}\text { Upper } \\
\text { third } \\
4(9.1 \%)\end{array}$ & $\begin{array}{c}\text { Middle } \\
\text { third } \\
13(29.5 \%)\end{array}$ & $\begin{array}{c}\text { Lower } \\
\text { third } \\
24(54.5 \%)\end{array}$ & $\begin{array}{c}\text { Multiple } \\
\text { segments } \\
3(6.8 \%)\end{array}$ \\
\hline $\begin{array}{l}\text { Peptic injury } \\
(n=24)\end{array}$ & $0(0 \%)$ & $0(0 \%)$ & $24(100 \%)$ & $0(0 \%)$ \\
\hline $\begin{array}{l}\text { Radiotherapy } \\
(\mathrm{n}=8)\end{array}$ & $3(37.5 \%)$ & $5(62.5 \%)$ & $0(0 \%)$ & $0(0 \%)$ \\
\hline $\begin{array}{l}\text { Idiopathic } \\
(n=7)\end{array}$ & $1(14.3 \%)$ & $6(85.7 \%)$ & $0(0 \%)$ & $0(0 \%)$ \\
\hline $\begin{array}{l}\text { Corrosive injury } \\
(n=3)\end{array}$ & $0(0 \%)$ & $0(0 \%)$ & $0(0 \%)$ & $3(100 \%)$ \\
\hline $\begin{array}{l}\text { Eosinophilic } \\
\text { esophagitis }(n=2)\end{array}$ & $0(0 \%)$ & $2(100 \%)$ & $0(0 \%)$ & $0(0 \%)$ \\
\hline
\end{tabular}

$\mathrm{P}<0.001$ 


\section{| Original Article}

Table 4: Number of sessions of EBD required for different etiology of benign esophageal stricture

\begin{tabular}{|c|c|c|c|c|}
\hline \multirow{2}{*}{$\begin{array}{l}\text { Etiology of be- } \\
\text { nign esophageal } \\
\text { stricture }\end{array}$} & \multirow[b]{2}{*}{$\begin{array}{c}\text { One } \\
25(56.8 \%)\end{array}$} & \multicolumn{3}{|c|}{ Number of sessions of EBD } \\
\hline & & $\begin{array}{c}\text { Two } \\
8(18.2 \%)\end{array}$ & $\begin{array}{c}\text { Three } \\
10(22.7 \%)\end{array}$ & $\begin{array}{l}\text { Four } \\
1(2.3 \%)\end{array}$ \\
\hline $\begin{array}{l}\text { Peptic injury (n } \\
=24 \text { ) }\end{array}$ & $21(87.5 \%)$ & $3(12.5 \%)$ & $0(0 \%)$ & $0(0 \%)$ \\
\hline $\begin{array}{l}\text { Radiotherapy } \\
(n=8)\end{array}$ & $0(0 \%)$ & $2(25 \%)$ & $6(75 \%)$ & $0(0 \%)$ \\
\hline Idiopathic $(n=7)$ & $4(57.1 \%)$ & $3(42.9 \%)$ & $0(0 \%)$ & $0(0 \%)$ \\
\hline $\begin{array}{l}\text { Corrosive injury } \\
(n=3)\end{array}$ & $0(0 \%)$ & $0(0 \%)$ & $2(66.7 \%)$ & $1(33.3 \%)$ \\
\hline $\begin{array}{l}\text { Eosinophilic } \\
\text { esophagitis ( } n \\
=2 \text { ) }\end{array}$ & $0(0 \%)$ & $0(0 \%)$ & $2(100 \%)$ & $0(0 \%)$ \\
\hline
\end{tabular}

$\mathrm{P}<0.001$

\section{DISCUSSION:}

The previous studies have shown that most of the benign esophageal strictures are caused by the peptic stricture resulting from the long-standing gastroesophageal reflux. ${ }^{15,16}$ Our study has also shown that the peptic stricture was responsible for more than half of all benign esophageal strictures. However, corrosive injury was found as the commonest cause of benign esophageal stricture in some other studies. ${ }^{17-19}$ In our study, corrosive injury accounted for only $6.8 \%$ of all strictures. The current study did not show any statistically significant gender and age group preference for the benign esophageal stricture.

The symptomatic relief of esophageal obstruction caused by benign esophageal stricture is done by balloon dilation or bougie dilation. ${ }^{10}$ The bougie dilation involves both longitudinal shearing and radial force exerted on the stricture, while EBD involves only radial exertion of force. The EBD is performed under direct vision in comparison to the blind insertion for bougie. By only exerting radial force in a controlled fashion

\section{REFERENCES:}

1. Siersema PD. Treatment options for esophageal strictures. Nat Clin Pract Gastroenterol Hepatol 2008;5:142-52

2. McLean GK, Cooper GS, Hartz WH, et al. Radiologically guided balloon dilatation of gastrointestinal strictures. Part I. Technique and factors influencing procedural success. Radiology 1987;165:35-40.

3. de Lange EE, Shaffer HA. Anastomotic strictures of the under direct visualisation, balloon dilation, is supposed to have an advantage in terms of perforation risk. Balloon dilation avoids the need for repeated passage of graded bougies to reach the desired diameter, and as such the patients could tolerate it better. However, the prior studies have shown that there is no significant difference between balloon and bougie dilation in treatment of benign strictures of esophagus in terms of complications and incidence of recurrence..$^{20}$

In our study, EBD was considered for the dilation of benign esophageal stricture. Some previous studies have shown that the perforation rate associated with the dilation of benign esophageal strictures is between 0.1 and 0.3 percent. ${ }^{21-26}$ Perforation rate is higher with complex strictures and radiation-induced strictures. ${ }^{27,28}$ The perforation rate may be influenced not only by the nature of the stricture, but also by the experience of endoscopist. One study indicated that the perforation rate was 4 times greater with an inexperienced endoscopist. ${ }^{29}$ In our study, we didn't have any events of perforation after the procedure of EBD.

There are certain limitations in our study as well. We had smaller sample size and the follow up of the patient was not prolonged. In order to assess the recurrence of the stricture, at least one year follow-up would have been significant. However, we had the follow-up of the patient of only 6 months. The idiopathic variety of $15.9 \%$ of benign esophageal stricture in our study could be due to certain unidentified causes, which we might have missed during the investigations.

In conclusion, peptic stricture was the commonest cause of benign esophageal stricture followed by post-radiotherapy, idiopathic, corrosive ingestion and eosinophilic esophagitis in the western region of Nepal. The stricture caused by radiotherapy, corrosive agent and eosinophilic esophagitis required more sessions of EBD. When performed carefully by an experienced endoscopist, through-the-scope EBD is safe and effective in treating benign esophageal strictures.

Conflict of interest: None declared.

upper gastrointestinal tract: Results of balloon dilatation. Radiology 1988;167:45-50.

4. Maynar M, Guerra C, Reyes R et al. Esophageal strictures, balloon dilatation. Radiology 1988;167:703-6.

5. Starck E, Paolucci V, Herzer M, et al. Esophageal stenosis treatment with balloon catheters. Radiology 1984;153: 637-40.

6. Dawson SL, Mueller PR, Ferrucci JT et al. Severe 
esophageal strictures: Indications for balloon catheter dilatation. Radiology 1984;153:631-5.

7. Quine MA, Bell GD, McCloy RF, et al. Prospective audit of perforation rates following upper gastrointestinal endoscopy in two regions of England. $\mathrm{Br} J$ Surg 1995;82:530-3.

8. Tulman AB, Boyce HW. Complications of oesophageal dilation and guidelines for their prevention. Gastrointest Endosc 1981;27:229-34.

9. McLean GK, Le Veen RF. Sheer stress in the performance of esophageal dilatation, comparison of balloon dilatation and bougienage. Radiology 1989; 172:983-6.

10. American Society for Gastrointestinal Endoscopy. The role of endoscopy in the evaluation and management of dysphagia. Gastrointestinal endoscopy. 2014;79:191201.

11. Abele JE. The physics of esophageal dilatation. Hepatogastroenterology 1992;39:486-9.

12. Dryden GW, McClave SA. Methods of treating dysphagia caused by benign esophageal strictures. Tech Gastrointest Endosc 2001;3:135-43.

13. Egan JV, Baron TH, Adler DG, et al. Standards of Practice Committee: Esophageal dilation. Gastrointest Endosc 2006; 63:755-60.

14. Foster DR. Routine chest radiography following endoscopic esophageal dilation for benign peptic esophageal strictures, Aust Radiol 1998;42:33.

15. Patterson DJ, Graham DY, Smith JL, et al. Natural history of benign esophageal stricture treated by dilatation. Gastroenterology 1983; 85:346-50.

16. Marks RD, Richter JE. Peptic strictures of the esophagus. Am J Gastroenterol 1993; 88:1160-73.

17. Varudkar AS, Deshmukh SN, Vitekar DD. Management of benign oesophageal strictures: our experience at tertiary care centre. Int Surg J 2017;4:1044-8.

18. Lahoti D, Broor SL. Corrosive injury to upper gastrointestinal tract. Indian J Gastroenterol. 1993;12:135-41.
19. Zargar SA, Kocher R, Nagi B, et al. Ingestion of corrosive acids. Spectrum of injury in upper gastrointestinal tract and natural history. Gastroenterolgy. 1989;97:702-7.

20. Cox JG, Winter RK, Maslin SC, et al. Balloon or Bougie Dilation of Benign Esophageal Stricture? Dig Dis Sci 1994;39:2099-101.

21. Mandelstam P, Sugawa C, Silvis SE, et al. Complications associated with esophagogastroduodenoscopy and with esophageal dilation. Gastrointest Endosc 1976; 23:16.

22. Pereira-Lima JC, Ramires RP, Zamin I Jr, et al. Endoscopic dilation of benign esophageal strictures: report on 1043 procedures. Am J Gastroenterol 1999; 94:1497.

23. Hernandez LV, Jacobson JW, Harris MS. Comparison among the perforation rates of Maloney, balloon, and savary dilation of esophageal strictures. Gastrointest Endosc 2000; 51:460-2.

24. Piotet E, Escher A, Monnier P. Esophageal and pharyngeal strictures: report on 1,862 endoscopic dilatations using the Savary-Gilliard technique. Eur Arch Otorhinolaryngol 2008; 265:357-364.

25. Karnak I, Tanyel FC, Büyükpamukçu N, et al. Esophageal perforations encountered during the dilation of caustic esophageal strictures. J Cardiovasc Surg (Torino) 1998; 39:373-7.

26. Silvis SE, Nebel O, Rogers G, et al. Endoscopic complications. Results of the 1974 American Society for Gastrointestinal Endoscopy Survey. JAMA 1976; 235:92830.

27. Hernandez LV, Jacobson JW, Harris MS. Comparison among the perforation rates of Maloney, balloon, and Savary dilation of esophageal strictures. Gastrointest Endosc 2000;51:460-2.

28. Clouse RE. Complications of endoscopic gastrointestinal dilation techniques. Gastrointest Endosc Clin N Am 1996;6:323-41.

29. Quine MA, Bell GD, McCloy RF, et al. Prospective audit of perforation rates following upper gastrointestinal endoscopy in two regions of England. $\mathrm{Br} J$ Surg 1995;82:530-3. 